\title{
Induction of $\Delta$ FosB in Reward-Related Brain Structures after Chronic Stress
}

\author{
Linda I. Perrotti, ${ }^{1}$ Yuki Hadeishi, ${ }^{2}$ Paula G. Ulery, ${ }^{1}$ Michel Barrot, ${ }^{1}$ Lisa Monteggia, ${ }^{1}$ Ronald S. Duman, ${ }^{2}$ and \\ Eric J. Nestler ${ }^{1}$ \\ ${ }^{1}$ Department of Psychiatry and Center for Basic Neuroscience, The University of Texas Southwestern Medical Center, Dallas, Texas 75390-9070, and \\ ${ }^{2}$ Laboratory of Molecular Psychiatry, Yale University School of Medicine, New Haven, Connecticut 06508
}

Acute and chronic stress differentially regulate immediate-early gene (IEG) expression in the brain. Although acute stress induces c-Fos and FosB, repeated exposure to stress desensitizes the c-Fos response, but FosB-like immunoreactivity remains high. Several other treatments differentially regulate IEG expression in a similar manner after acute versus chronic exposure. The form of FosB that persists after these chronic treatments has been identified as $\triangle$ FosB, a splice variant of the fos $B$ gene. This study was designed to determine whether the FosB form induced after chronic stress is also $\Delta$ FosB and to map the brain regions and identify the cell populations that exhibit this effect. Western blotting, using an antibody that recognizes all Fos family members, revealed that acute restraint stress caused robust induction of c-Fos and full-length FosB, as well as a small induction of $\Delta \mathrm{FosB}$, in the frontal cortex (fCTX) and nucleus accumbens (NAc). The induction of c-Fos (and to some extent full-length FosB) was desensitized after $10 \mathrm{~d}$ of restraint stress, at which point levels of $\Delta$ FosB were high. A similar pattern was observed after chronic unpredictable stress. By use of immunohistochemistry, we found that chronic restraint stress induced $\triangle$ FosB expression predominantly in the fCTX, NAc, and basolateral amygdala, with lower levels of induction seen elsewhere. These findings establish that chronic stress induces $\Delta$ FosB in several discrete regions of the brain. Such induction could contribute to the long-term effects of stress on the brain.

Key words: c-Fos; stress; nucleus accumbens; prefrontal cortex; amygdala; reward

\section{Introduction}

Acute and chronic stress differentially regulate the expression of Fos family transcription factors in the brain. Many studies have shown that acute restraint stress or several other types of acute stress induce c-Fos expression in numerous brain areas, prominent among which are the frontal cortex, nucleus accumbens (NAc), lateral septum, thalamus, paraventricular nucleus of the hypothalamus, and hippocampus (Melia et al., 1994; Senba et al., 1994; Senba and Ueyama, 1997; Bubser and Deutch, 1999; Morrow et al., 2000). In contrast, repeated exposure to stress desensitizes this c-Fos response in many, but not all, of these brain regions (Melia et al., 1994; Umemoto et al., 1997; Stamp and Herbert, 1999).

Less is known about stress regulation of other Fos family members, although stress induction of FosB exhibits a very different time course compared with that of c-Fos. Although acute stress increases FosB-like immunoreactivity in several brain areas as seen for c-Fos, FosB levels remain high even after chronic stress (Umemoto et al., 1997; Stamp and Herbert, 1999, 2001). How-

Received 0ct. 28, 2003; revised Sept. 14, 2004; accepted Sept. 14, 2004.

This work was supported by grants from the National Institute of Mental Health and the National Institute on Drug Abuse.

Correspondence should be addressed to Dr. Eric J. Nestler, Department of Psychiatry, The University of Texas Southwestern Medical Center, 5323 Harry Hines Boulevard, Dallas, TX 75390-9070. E-mail: eric.nestler@utsouthwestern.edu.

M. Barrot's present address: Unité Mixte de Recherche 7519, Centre National de la Recherche Scientifique, Université Louis Pasteur, 67084 Strasbourg, France.

DOI:10.1523/JNEUROSCI.2542-04.2004

Copyright $\odot 2004$ Society for Neuroscience ～0270-6474/04/2410594-09\$15.00/0 ever, it has remained unknown whether this FosB-like immunoreactivity that persists in the brain with chronic stress represents full-length FosB or its truncated splice variant, $\Delta$ FosB.

Induction of Fos family proteins by several other chronic treatments, effects seen most prominently in the NAc and dorsal striatum, exhibits some similarities to the induction of these proteins by stress. As with stress, acute exposure to cocaine, related stimulants, or several other drugs of abuse, or to a firstgeneration antipsychotic drug like haloperidol, induces c-Fos and FosB in these brain regions, whereas chronic drug exposure desensitizes the c-Fos response (Hope et al., 1992, 1994b; Persico et al., 1993; Steiner and Gerfen, 1993; Daunais and McGinty, 1994; Hiroi and Graybiel, 1996; Moratalla et al., 1996; Rosen et al., 1998; Atkins et al., 1999). Also like stress, levels of FosB-like immunoreactivity remain high in the NAc and dorsal striatum after chronic drug exposure. We now know that the FosB-like immunoreactivity that persists with chronic drug exposure is $\Delta$ FosB and that induction of full-length FosB, like the induction of c-Fos, is desensitized (Hope et al., 1994b; Hiroi and Graybiel, 1996; Moratalla et al., 1996; Atkins et al., 1999). $\Delta$ FosB, unlike c-Fos and full-length FosB, accumulates with chronic drug exposure because of its very long half-life (Chen et al., 1997). As result, $\Delta \mathrm{FosB}$ is thought to mediate some of the longer-lasting transcriptional changes induced by drugs of abuse or antipsychotic drugs in the NAc and dorsal striatum (Nestler et al., 2001; McClung and Nestler, 2003).

The present study was undertaken to determine whether the 
FosB-like immunoreactivity induced in the brain after chronic stress is also $\Delta$ FosB and to characterize the brain regions and cell populations that exhibit this effect. We show here that chronic stress does indeed induce $\Delta$ FosB within the NAc and certain other brain regions, in particular, the frontal cortex and basolateral amygdala. Induction of $\Delta$ FosB by chronic stress could account for some of the functional adaptations that stress induces in these brain regions.

\section{Materials and Methods}

Restraint stress. Adult Sprague Dawley male rats (300-350 gm) were subjected to immobilization stress in Disposable Rodent Restrainers (Braintree Scientific, Braintree, MA) for $1 \mathrm{hr}$ daily over a period of 1-10 consecutive days. Other groups of rats were subjected to chronic unpredictable stress for $10 \mathrm{~d}$ exactly as described previously (Ortiz et al., 1996). Control rats were either not handled or were handled daily but not subjected to stress.

Western blots of brain. Brain regions were isolated from stressed and control rats by gross dissection or by obtaining punches from 1-mmthick coronal sections and then subjected to Western blotting, which was performed according to published procedures (Hope et al., 1994a). Brain samples were homogenized in a buffer containing $20 \mathrm{mM}$ HEPES, $0.4 \mathrm{M}$ $\mathrm{NaCl}, 20 \%$ glycerol, $5 \mathrm{~mm} \mathrm{MgCl}, 0.5 \mathrm{~mm}$ EDTA, $0.1 \mathrm{~mm}$ EGTA, 1\% $\mathrm{NP}-40,1 \mathrm{~m}$ DTT, $1 \mathrm{~m} \mathrm{PMSF}$, and $5 \mu \mathrm{l} / \mathrm{ml}$ of a protease inhibitor mixture. Aliquots (containing $50 \mu \mathrm{g}$ of protein) were then applied to a $10 \%$ acrylamide $/ 0.27 \% \mathrm{~N}, \mathrm{~N}$-methylenebisacrylamide resolving gel for SDS-PAGE overnight at $75 \mathrm{~V}$ and then electrotransferred to nitrocellulose at $200 \mathrm{~mA}$ for $3 \mathrm{hr}$. The blots were blocked with four $15 \mathrm{~min}$ changes of $2 \%$ (for pan-Fos antibody; kindly provided by Dr. Michael Iadarola, National Institute of Dental Research, National Institutes of Health, Bethesda, MD) or $0.5 \%$ (for anti-FosB antibodies) (Chen et al., 1995) nonfat dry milk in PBS-Tween (PBS containing 0.1\% Tween 20). The blots were washed four times for 15 min each in blocking buffer and incubated for 2 hr in a 1:4000 dilution of goat anti-rabbit antibody conjugated to horseradish peroxidase (Vector Laboratories, Burlingame, CA) in blocking buffer. The blots were washed eight times for 15 min each with PBSTween alone, developed with the enhanced chemiluminescence (ECL) system (Amersham Biosciences, Arlington Heights, IL), and exposed to Hyperfilm-ECL (Amersham Biosciences) for 5-60 sec. Levels of Fos protein immunoreactivity were quantified either by measuring the optical density of specific bands using an image analysis system or by measuring light intensity using the Bio-Rad (Hercules, CA) GS-363 phosphorimager.

Immunohistochemistry. Eighteen to $24 \mathrm{hr}$ after their last treatment, animals were deeply anesthetized with chloral hydrate and perfused intracardially with $200 \mathrm{ml}$ of $0.01 \mathrm{M}$ PBS, followed by $400 \mathrm{ml}$ of $4 \%$ paraformaldehyde in $0.01 \mathrm{~m}$ PBS. Brains were removed and stored overnight in $4 \%$ paraformaldehyde at $4^{\circ} \mathrm{C}$. The next morning, brains were transferred to a $20 \%$ glycerol in $0.01 \mathrm{M}$ PBS solution for cryoprotection. Coronal sections $(40 \mu \mathrm{m})$ were cut on a freezing microtome (Leica, Bannockburn, IL) and then processed for immunohistochemistry. FosB and $\Delta$ FosB immunoreactivities were detected using rabbit polyclonal antisera raised against two distinct regions of the FosB protein. One antiserum, prepared in our laboratory, was raised against a portion of the FosB C-terminal region, which is missing from $\Delta$ FosB (amino acids $317-$ 334 ) and recognizes full-length FosB but not $\Delta$ FosB (see Fig. $2 A$ ). The other antisera were raised against an $\mathrm{N}$-terminal region of FosB and recognize both FosB and $\Delta$ FosB [SC-48 (Santa Cruz Biotechnology, Santa Cruz, CA) and a similar antibody raised in our own laboratory; results with the two antibodies were equivalent]. c-Fos immunoreactivity was detected using an antibody specific for this protein (SC-52, 1:5000; Santa Cruz Biotechnology).

FosB- or c-Fos-like staining was revealed by use of the avidin-biotin peroxidase method. Sections were first treated with $0.3 \% \mathrm{H}_{2} \mathrm{O}_{2}$ to destroy endogenous peroxidases and then incubated for $1 \mathrm{hr}$ in $0.3 \%$ Triton $\mathrm{X}$ and $3 \%$ normal goat serum to minimize nonspecific labeling. Tissue sections were then incubated overnight at room temperature in $1 \%$ normal goat serum, $0.3 \%$ Triton $\mathrm{X}$, and anti-FosB(N-terminus) antibody (SC-48; 1:5000). Sections were washed, placed for $1.5 \mathrm{hr}$ in a 1:200 dilu- tion of biotinylated goat anti-rabbit Ig (DakoCytomation, Carpinteria, CA), washed, and placed for $1.5 \mathrm{hr}$ in a 1:200 dilution of avidin-biotin complex from the Elite kit (Vector Laboratories). Peroxidase activity was visualized by reaction with diaminobenzidine (Vector Laboratories). Once FosB N-terminal immunoreactivity was detected, consecutive brain sections were studied by double fluorescent labeling (see below for protocol details) with the anti-FosB(N-terminus) and anti-FosB(Cterminus) antibodies to confirm that the protein induced by chronic stress was indeed $\Delta \mathrm{FosB}$.

Coded slides were used to count the number of FosB-immunoreactive cells throughout each brain region of interest. The code was not broken until analysis for an individual experiment was complete. The total number of FosB-positive cells was specifically counted in several regions of interest, namely the frontal cortex, NAc (core and shell), and basolateral, basomedial, and central medial amygdala using stereological methods (West et al., 1991). The analysis was performed using a Leeds microscope equipped with an $x-y-z$ stage connected to a personal computer running Bioquant Nova (Bioquant Image Analysis, Nashville, TN). Four equally spaced sections spanning the entire brain structure were analyzed using an image analysis system (Bioquant Nova; Bioquant Image Analysis).

Double-labeling immunohistochemistry and in situ hybridization methods. Immunohistofluorescence was used to double- or triple-label for $\Delta$ FosB (SC-48, 1:200; Santa Cruz Biotechnology) and for several other proteins as described previously (Barrot et al., 2002; Shaw-Lutchman et al., 2002). These included glial fibrillary acidic protein (GFAP; 1:500; Dako, High Wycombe, UK), parvalbumin (MAB1572, 1:500; Chemicon, Temecula, CA), calbindin (AB1778, 1:500; Chemicon), choline acetyltransferase (AB5042, 1:500; Chemicon), calretinin (1:500; Chemicon), and $\mathrm{FosB}$ (C terminus) (1:500). The proteins were visualized using $\mathrm{CY} 2$, CY3, or CY5 fluorophore-labeled secondary antibodies. Localization of protein expression was performed on a confocal microscope (Axiovert 100; LSM 510 with META emission wavelengths of 488, 543, and 633; Zeiss, Thornwood, NY). Images presented here were captured on this system and represent a $1-\mu \mathrm{m}$-thick section through a Z-plane.

A combined immunohistochemistry-in situ hybridization method was also used according to published procedures (Kelz et al., 1999). Brain sections through the striatum were immunolabeled for $\Delta$ FosB using an $\mathrm{N}$-terminus antibody and the avidin-biotin complex method as described above. The sections were then incubated with ${ }^{35} \mathrm{~S}$-labeled riboprobes complemenary to exon 4 of rat prodynorphin or to exon 3 of rat proenkephalin, or to the vesicular glutamate transporter 1 (vGluT1). The vGLUT1 probe (from Drs. Robert E. Edwards and Robert Fremeau, University of California San Francisco, San Francisco, CA) is an oligonucleotide of the following sequence: 5'-GAGCTTGGCTTCTCCGATGGCATCCTCAATGTATTTGCGCTCCTC-3'. The sections were then washed, dried, and dipped in NT2B emulsion (Eastman Kodak, Rochester, NY) according to published procedures (Kelz et al., 1999). Emulsions were developed 2 weeks later and counterstained with cresyl violet.

Viral vectors. $\mathrm{cDNAs}$ for $\triangle \mathrm{FosB}$ and FosB were inserted into the herpes simplex virus (HSV) amplicon HSV-PrPUC and packaged into the virus using the helper $5 d l 1.2$, as described previously (Neve et al., 1997; Carlezon et al., 1998; Barrot et al., 2002). For viral injections, animals were anesthetized with sodium pentobarbital $(60 \mathrm{mg} / \mathrm{kg}$, i.p.) and given atropine $(0.25 \mathrm{mg} / \mathrm{kg}$, s.c.) to minimize bronchial secretions. Afterward, animals were given bilateral microinjections $(0.5 \mu \mathrm{l}$ on each side over 10 min) of either HSV- $\Delta$ FosB or HSV-FosB into the NAc shell (relative to bregma: anteroposterior, +1.9 ; lateral, +2.4 ; dorsoventral, $-6.7 \mathrm{~mm}$ below dura; with a $10^{\circ}$ lateral angle), as described previously (Carlezon et al., 1998; Barrot et al., 2002). All injection placements were checked at the end of the experiment.

$\Delta$ FosB and FosB immunoblotting. In an experiment to confirm the specificity of the two types of anti-FosB antibodies used, PC12 cells (Clontech, Palo Alto, CA) were infected with HSV- $\Delta$ FosB or HSV-FosB $(0.4-0.8 \mu \mathrm{l} /$ well $)$. Approximately $36 \mathrm{hr}$ after infection, cells were washed and harvested, and aliquots (containing $25 \mu \mathrm{g}$ of protein) were subjected to SDS-PAGE. Proteins in resulting gels were transferred onto nitrocellulose membranes, which were then stained with Ponceau (to confirm equal loading and transfer) and immunoblotted with our new anti- 
FosB(N-terminus) antibody (1:1000) or antiFosB(C-terminus) antibody (1:1000) by use of standard procedures. Results with the commercially available SC- 48 anti-FosB(N-terminus) antibody were identical to those obtained with our new antibody, which was raised against amino acids $1-16$ of FosB/ $\Delta$ FosB. Membranes were washed and then incubated with a goat anti-rabbit IgG conjugated to horseradish peroxidase (1:5000; Vector Laboratories). Membranes were washed, and protein bands were visualized on Kodak MR film by ECL (Pierce, Rockford, IL).

Statistical analysis. Significance was measured using one-way ANOVAs as well as Student's $t$ tests, which were corrected in all cases for multiple comparisons. Data are expressed as means \pm SEM. Statistical significance was defined as $p<$ 0.05 .

\section{Results}

Stress induction of Fos family proteins in brain: Western blot studies

As a first step to determine whether the FosB-like immunoreactivity induced in the brain by chronic stress represents fulllength FosB or $\Delta$ FosB, we subjected a group of rats to either a single episode of restraint stress or to daily episodes of restraint stress for $10 \mathrm{~d}$, with rats used $2 \mathrm{hr}$ after the last stress treatment. For this initial study, we analyzed the frontal cortex because this region has been reported previously to show robust induction of Fos family proteins after stress (Bruijnzeel et al., 1999; Morrow et al., 1999). The brain samples were analyzed by Western blotting using a pan-Fos antibody, which recognizes all known Fos family proteins. As shown in Figure 1, $A$ and $B$, acute stress induced high levels of several Fos family proteins in the frontal cortex, which we tentatively identified as c-Fos (52 kDa), FosB (46-48 kDa), Fra-1 or Fra-2 (Fosrelated antigen-1 or $-2 ; 41 \mathrm{kDa})$, and $\Delta$ FosB $(33 \mathrm{kDa})$. A very different pattern was observed after chronic stress, where the predominant Fos family protein was a broad band of 35-37 kDa, which represents modified isoforms of $\Delta$ FosB (see be-

low). In addition, the ability of this last stress treatment to induce the other bands was mostly desensitized. The 35-37 kDa band, which predominated after chronic stress, also persisted for a longer period of time, because it was present at almost equivalent levels $24 \mathrm{hr}$ after the last stress treatment. This is in contrast to all of the other Fos family proteins, which returned to control levels within this $24 \mathrm{hr}$ period. In contrast to chronic stress, no induction of Fos family proteins was seen $24 \mathrm{hr}$ after a single, acute stress (data not shown).

This time-dependent pattern of induction of Fos family proteins in the frontal cortex by acute versus chronic stress is highly similar to that seen in response to other treatments, e.g., chronic electroconvulsive seizures in the frontal cortex (Hope et al., 1994a), or chronic administration of a drug of abuse (Hope et al.,
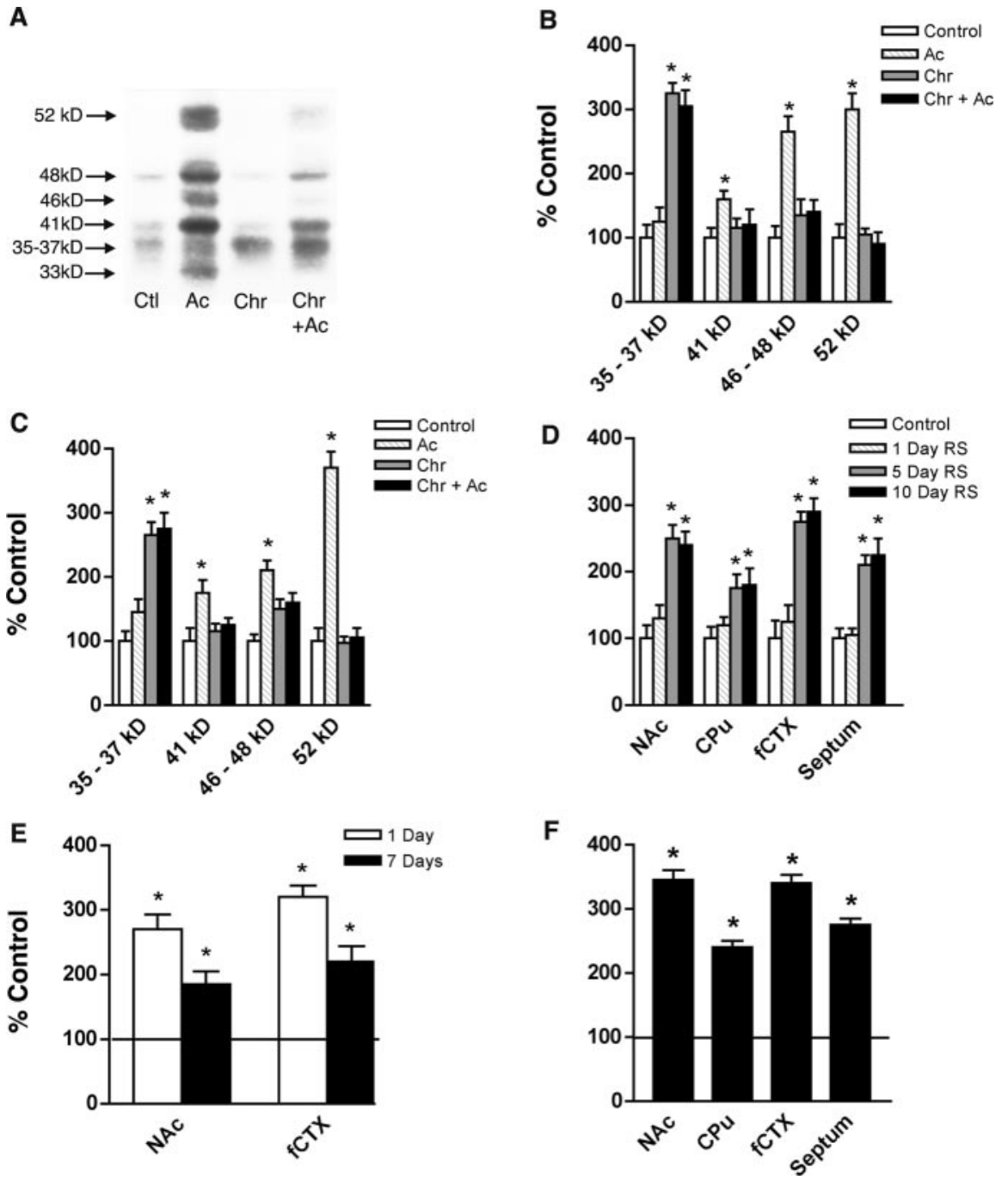

Figure 1. Induction of Fos family proteins in brain after acute and chronic stress. $A$, Representative Western blot, using a pan-Fos antibody, showing induction of Fos family proteins in the frontal cortex under four conditions: control (Ctl), non-handled stress. $B$, Levels of Fos family protein induction in the frontal cortex revealed by Western blotting were quantified and expressed

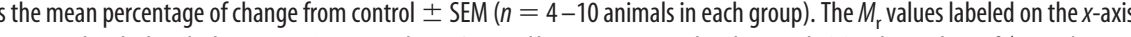
a) induction by acute and chronic stress in the NAc. D, Time course of $\triangle \mathrm{FosB}(35-35 \mathrm{kDa})$ expression in the NAc, dorsal striatum $\Delta$ FosB isoforms in the NAc and frontal cortex after 1 or $7 \mathrm{~d}$ of withdrawal from chronic $(10 \mathrm{~d})$ restraint stress. $F$, Levels of $35-37 \mathrm{kDa}$ $\triangle$ FosB isoforms in the NAc, CPu, frontal cortex, and lateral septum after $10 \mathrm{~d}$ of chronic unpredictable stress.

1994b; Moratalla et al., 1996) or antipsychotic drugs (Doucet et al., 1996; Hiroi and Graybiel, 1996; Atkins et al., 1999) in the striatum. In each of these studies, the identification of the 35-37 $\mathrm{kDa}$ band as modified isoforms of $\Delta \mathrm{FosB}$ and the $33 \mathrm{kDa}$ protein as the native form of the protein is based on the following lines of evidence: (1) overexpression of $\triangle$ FosB cDNA in cultured cells initially produces the $33 \mathrm{kDa}$ band, which is gradually replaced by the 35-37 kDa band during more prolonged expression (Chen et al., 1997; Alibhai et al., 2004); (2) the $33 \mathrm{kDa}$ and $35-37 \mathrm{kDa}$ bands are both recognized by anti-FosB(N-terminus) antibody and not by anti-FosB(C-terminus) antibody (Hope et al., 1994b; Chen et al., 1995, 1997); and (3) both the 33 and 35-37 kDa bands are lost in fosB knock-out mice (Hiroi et al., 1997, 1998; Mandelzys et al., 1997). The nature of the modifications that convert the $33 \mathrm{kDa}$ band to the $35-37 \mathrm{kDa}$ band has remained unknown, but 
recent evidence suggests that phosphorylation of the protein is involved (Ulery and Nestler, 2004).

The effects of acute and chronic stress on levels of Fos family proteins in the frontal cortex were mirrored in certain other brain regions. The most dramatic of these regions was the NAc, where induction of c-Fos, FosB, and Fra-1/2 after acute stress, their desensitization after chronic stress, and the unique induction of the $35-37 \mathrm{kDa}$ isoforms of $\Delta$ FosB after chronic stress were as prominent as those seen in the frontal cortex (Fig. 1C). Qualitatively similar results were obtained for the lateral septum, dorsal striatum, amygdala, and locus ceruleus, although the magnitude of induction of the various proteins after acute and chronic stress was generally not as large as that seen in the frontal cortex and NAc (data not shown). In contrast, no induction of $\Delta$ FosB (or any other Fos family protein) was apparent after chronic stress in other regions analyzed, which included the hippocampus, parietal cortex, and ventral tegmental area (data not shown).

We next analyzed the time course by which repeated restraint stress caused the induction of the $35-37 \mathrm{kDa} \Delta$ FosB isoforms. As mentioned earlier, no induction was seen $24 \mathrm{hr}$ after a single period of restraint, but the effect became near-maximal after $5 \mathrm{~d}$ of daily restraint stress. No additional induction was seen after $10 \mathrm{~d}$ of daily restraint stress. This was true in all regions analyzed, e.g., in the frontal cortex, NAc, lateral septum, and dorsal striatum (Fig. 1D). Moreover, in each of these regions, levels of the $\Delta$ FosB isoforms remained significantly elevated 1 week after the last stress treatment, consistent with the highly stable nature of these isoforms (Fig. 1E).

A different form of chronic stress, chronic unpredictable stress, also led to the accumulation of the $35-37 \mathrm{kDa}$ isoforms of $\Delta$ FosB in the same brain regions affected by chronic restraint stress. In fact, the magnitude of $\Delta$ FosB induction tended to be greater with chronic unpredictable stress (Fig. $1 F$ ), perhaps because rats show less habituation to this form of stress (where the individual stresses vary from day to day) compared with restraint stress (Ortiz et al., 1996).

\section{Stress induction of Fos family proteins in brain: immunohistochemical studies}

Having identified $\Delta$ FosB as the predominant Fos family protein induced in the brain by chronic stress, we used immunohistochemistry, with an anti-FosB(N-terminus) antibody, to more precisely map regions of the brain that show this $\Delta \mathrm{FosB}$ response. Animals were subjected to $10 \mathrm{~d}$ of daily restraint stress and were analyzed $24 \mathrm{hr}$ after the last stress, at which time we know that the $35-37 \mathrm{kDa} \Delta$ FosB isoforms are the only Fos family proteins significantly elevated (Fig. 1). Chronic restraint stress increased FosB-like immunoreactivity above basal levels in numerous brain areas (Table 1; Fig. 2). The regions that showed the largest effect included several regions of the cerebral cortex, NAc, dorsal striatum, basolateral nucleus of the amygdala, lateral septum, supramammillary nucleus, and locus ceruleus. In general, this pattern was highly consistent with that observed by Western blotting (Fig. 1).

For these immunohistochemistry experiments, we used an $\mathrm{N}$-terminus antibody that recognizes both $\Delta$ FosB and full-length FosB. However, because Western blotting showed that $\Delta$ FosB, and not full-length FosB, is present after chronic stress, it is highly likely that the FosB-like immunoreactivity observed under these conditions represents $\Delta$ FosB. Consistent with this interpretation, we found that analysis of consecutive brain sections with an antibody directed against the $\mathrm{C}$ terminus of FosB, which recognizes full-length FosB but not $\Delta$ FosB, failed to detect any FosB-like
Table 1. Relative strength of $\Delta F$ osB induction for each brain region examined

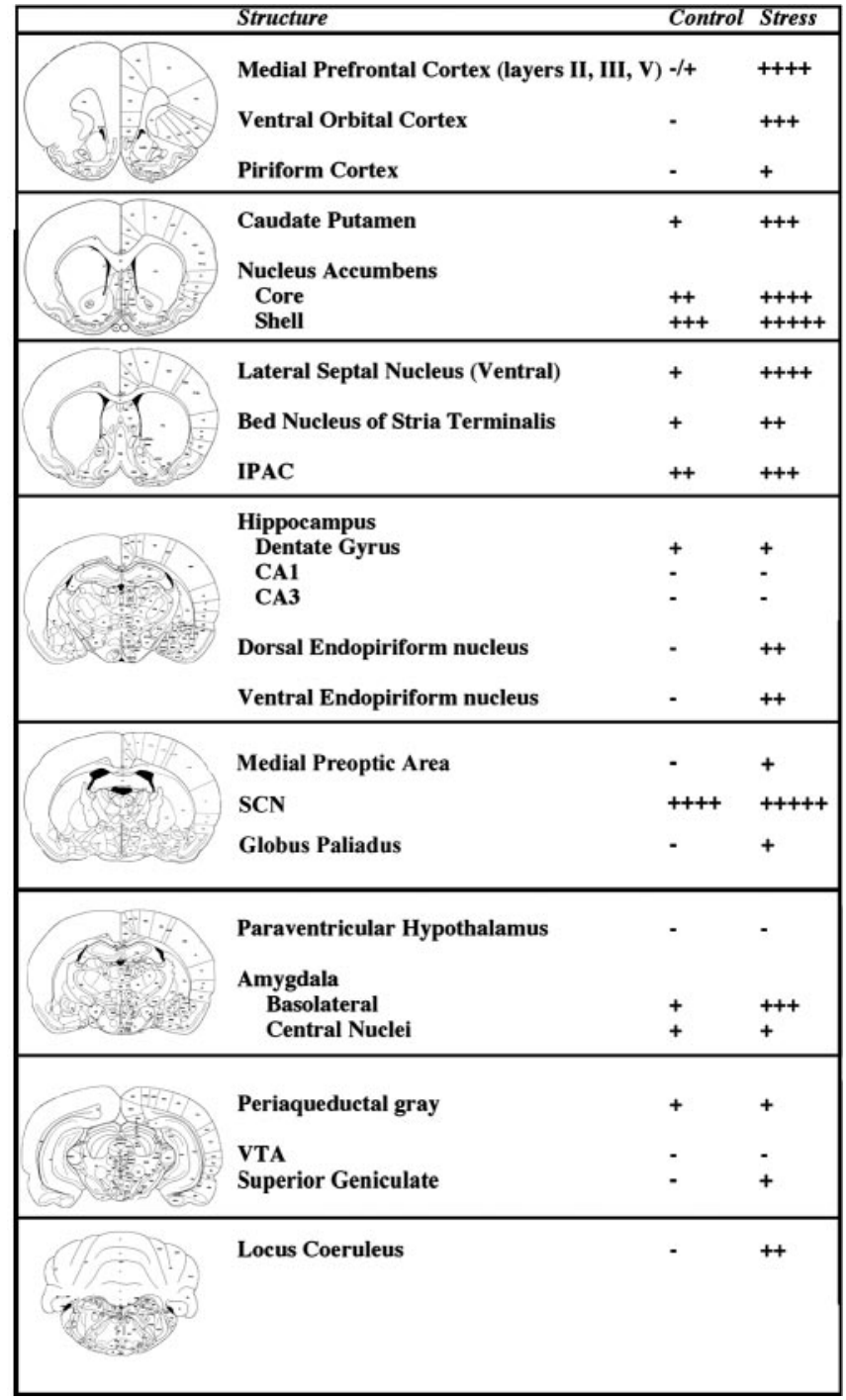

,$-<50$ FosB + nuclei $/ \mu \mathrm{m}^{2},+,<200$ FosB + nuclei $/ \mu \mathrm{m}^{2},++,<300$ FosB + nuclei $/ \mu \mathrm{m}^{2},+++,<400$ FosB + nuclei $/ \mu \mathrm{m}^{2},++++,<500$ FosB + nuclei $/ \mu \mathrm{m}^{2},+++++,>600$ FosB + nulcei $/ \mu \mathrm{m}^{2}$.

immunoreactivity in the brains of chronically stressed animals (data not shown). The specificity of the antibodies used in these studies is demonstrated in Figure 3. Extracts of PC12 cells expressing $\Delta$ FosB or FosB were immunoblotted with the $\mathrm{N}$-terminus or C-terminus antibody. In a parallel experiment, $\Delta$ FosB or FosB was overexpressed in the NAc using HSV vectors and brain sections stained immunohistochemically with the $\mathrm{N}$-terminus and C-terminus antibodies. In both experiments, the results showed that the $\mathrm{N}$-terminus antibody recognizes both $\Delta$ FosB and FosB, whereas the $\mathrm{C}$-terminus antibody recognizes FosB only.

Induction of FosB-like immunoreactivity was quantified more precisely in three brain regions: the medial prefrontal cortex, NAc, and amygdala (Fig. 4). Interestingly, the NAc showed the highest basal levels of FosB-like immunoreactivity as well as a significant induction of FosB + cells after chronic stress. This effect was more apparent in the NAc core, although the shell subregion tended to show the same effect. The medial prefrontal cortex showed lower basal levels of FosB-like immunoreactivity, but almost a threefold induction after chronic stress. Within the amygdala, basal levels of FosB-like immunoreactivity were low 


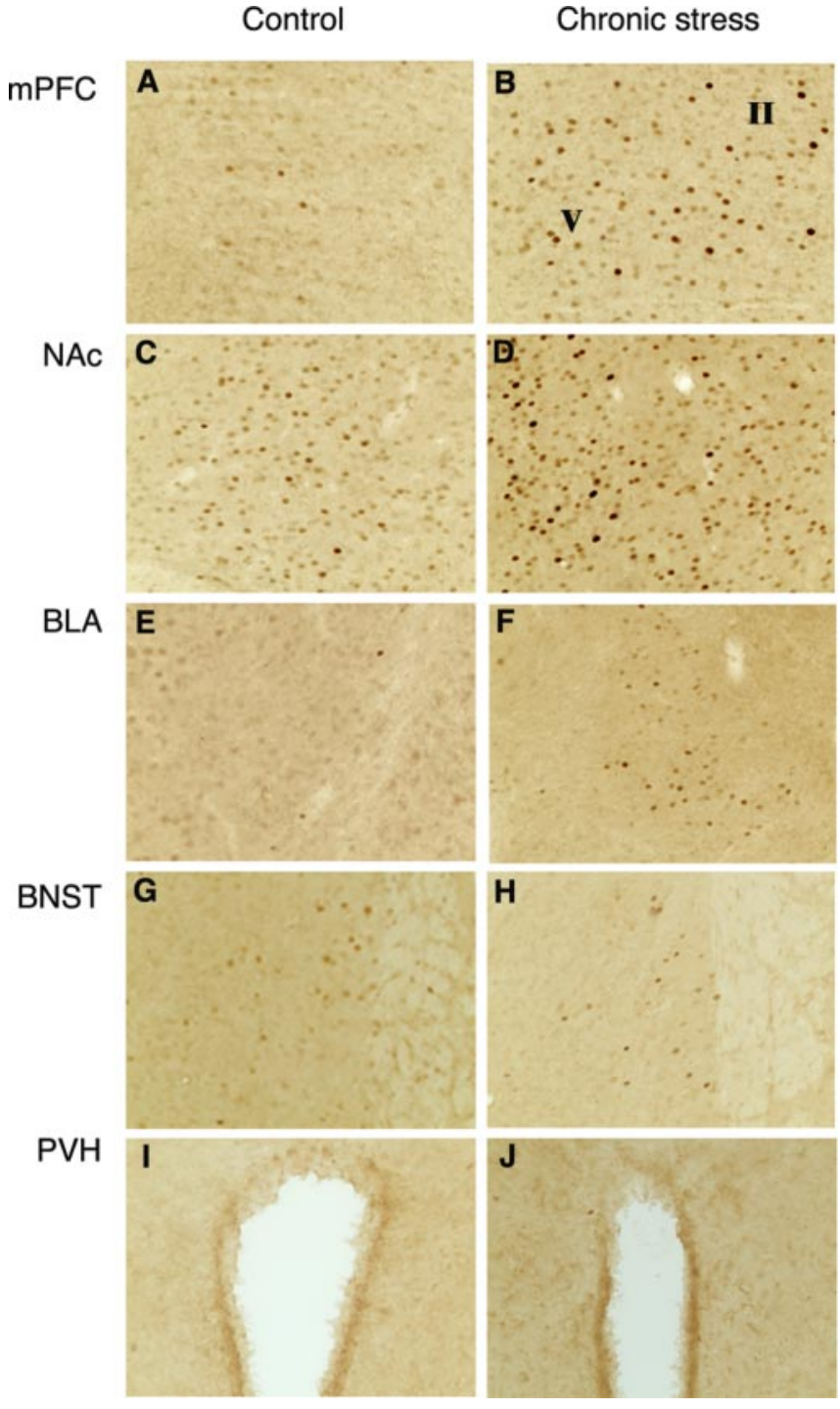

Figure 2. Induction of $\Delta \mathrm{FosB}$ in brain after $10 \mathrm{~d}$ of chronic restraint stress. Levels of FosB-like immunoreactivity were analyzed by immunohistochemistry using an anti-Fos $B$ (N-terminus) antibody in control $(A, C, E, G, I)$ and chronic stressed $(B, D, F, H, J)$ animals. Note that chronic restraint stress increased FosB-like immunoreactivity in the medial prefrontal cortex (mPFC; $A$, $B)$, NAc core $(C, D)$, and basolateral amygdala (BLA; $E, F)$. In contrast, chronic restraint stress did not induce FosB-like immunoreactivity in the bed nucleus of stria terminalis (BNST; $G, H$ ) or paraventricular nucleus of the hypothalamus (PVH; $I, J)$, areas in which $\mathrm{C}-\mathrm{Fos}$ and full-length FosB are induced after acute stress (see Fig. 5).

throughout the nucleus, whereas chronic stress caused a twofold induction selectively in the basolateral region. In contrast, stress had no effect on FosB-like immunoreactivity in the central or basal medial regions of the amygdala.

Interestingly, not all regions of the brain that show induction of c-Fos or FosB with acute stress show accumulation of $\Delta$ FosB after chronic stress. Prominent examples of this dissociation include the bed nucleus of the stria terminalis and paraventricular nucleus of the hypothalamus, both of which display robust induction of c-Fos and FosB with acute stress (as depicted in Fig. 5) but no significant accumulation of $\Delta$ FosB after chronic stress (Fig. 3).

\section{Cellular specificity of $\Delta$ FosB induction by chronic stress}

We used a series of neuronal markers to characterize the cell types within particular brain regions where chronic stress induces
A
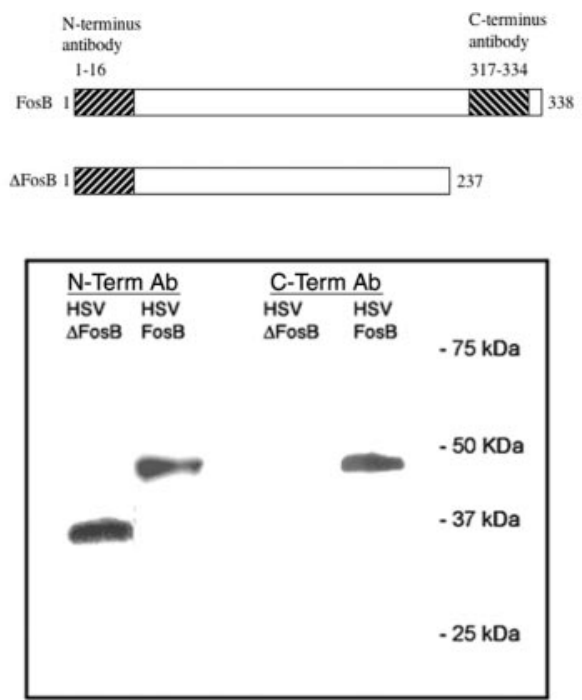

B

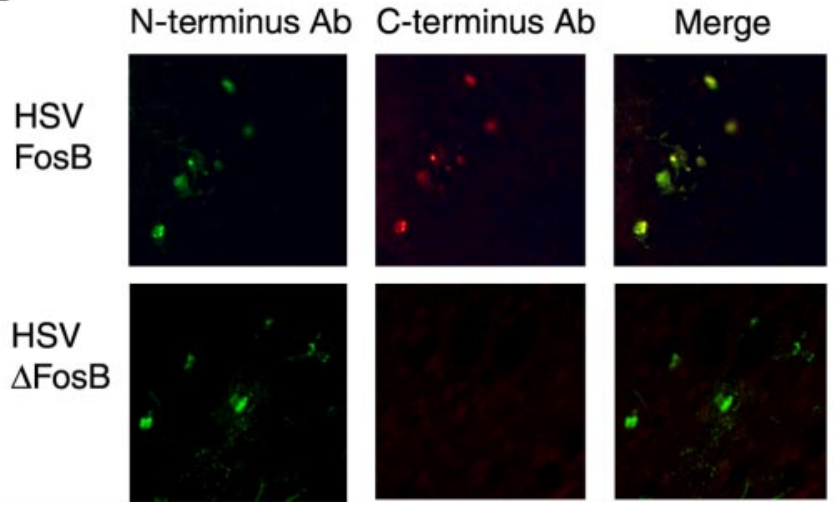

Figure 3. Specificity of anti-FosB(N-terminus) and anti-FosB(C-terminus) antibodies. $A$, Extracts of $\mathrm{PC} 12$ cells overexpressing FosB or $\triangle \mathrm{FosB}$, by use of HSV vectors, were subjected to Western blotting using an anti-FosB(N-terminus) or anti-FosB(C-terminus) antibody raised against the indicated portions of the proteins. B, Double-labeling immunohistochemistry using the anti-Fos $B$ (N-terminus) or anti-FosB(C-terminus) antibody through the NAc of animals injected with HSV-FosB and HSV- $\triangle$ Fos $B$ in this brain region. In $A$ and $B$, the N-terminus antibody stains both $\triangle$ FosB and FosB, whereas the C-terminus antibody stains FosB only.

$\Delta$ FosB. The first region studied was the NAc. The NAc, like the dorsal striatum, comprises multiple neuronal cell types (Gerfen, 1992; Graybiel, 1995). Approximately $90-95 \%$ of neurons in this region are GABAergic medium spiny projection neurons, which can be divided into two classes. One class expresses the neuropeptides dynorphin and substance $\mathrm{P}$ and projects directly back to the midbrain. The other class expresses the neuropeptide enkephalin and projects to the pallidum. Both classes of neurons are important in the regulation of NAc and dorsal striatal function. The NAc also contains smaller numbers of interneurons, including large cholinergic cells and several types of smaller GABAergic cells. Using double- and triple-labeling methods, we first found that $\Delta$ FosB was induced by chronic stress within neurons only, because $\Delta$ FosB was never colocalized with GFAP, an astroglial marker (Fig. $6 C$ ). Second, $\Delta$ FosB induction predominated in medium spiny neurons, being observed in approximately equal numbers in enkephalin + and in dynorphin + cells (Fig. 6A,B). There was also very sparse induction of $\Delta$ FosB in GABAergic interneurons (labeled with parvalbumin, calretinin, or calbindin), but no induction was seen in cholinergic interneurons (labeled with choline acetyltransferase) (Fig. 6C-E).

We next examined the prefrontal cortex. As can be seen in 


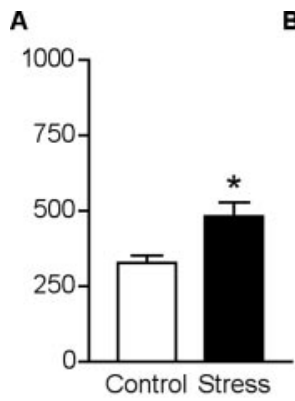

B

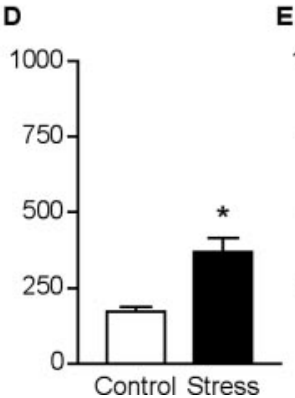

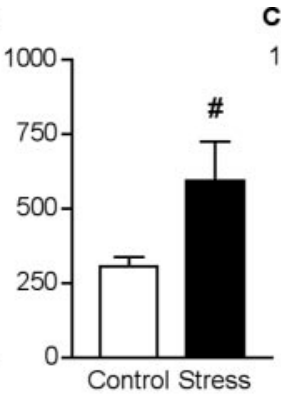

E

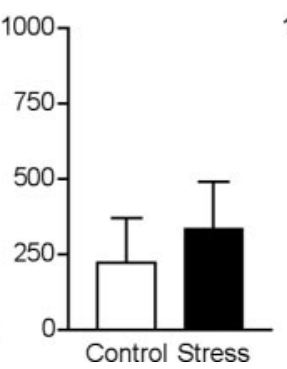

$\mathbf{F}$
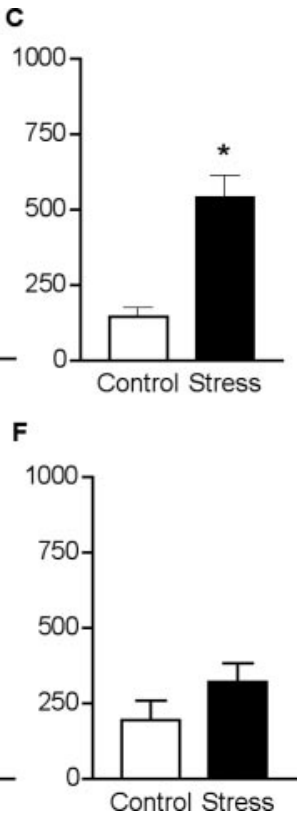

Figure 4. Quantification of $\Delta$ FosB induction in brain after $10 \mathrm{~d}$ of chronic restraint stress. The bar graphs show the mean density of Fos $B+$ cells in control animals and in animals subjected to chronic restraint stress in the NAc core $(A)$, NAc shell $(B)$, medial prefrontal cortex $(C)$, basolateral amygdala $(D)$, basomedial amygdala $(E)$, and central medial amygdala $(F)$. Data are expressed as mean \pm SEM ( $n=3-4$ animals in each group). ${ }^{*} p<0.05$ by $t$ test.
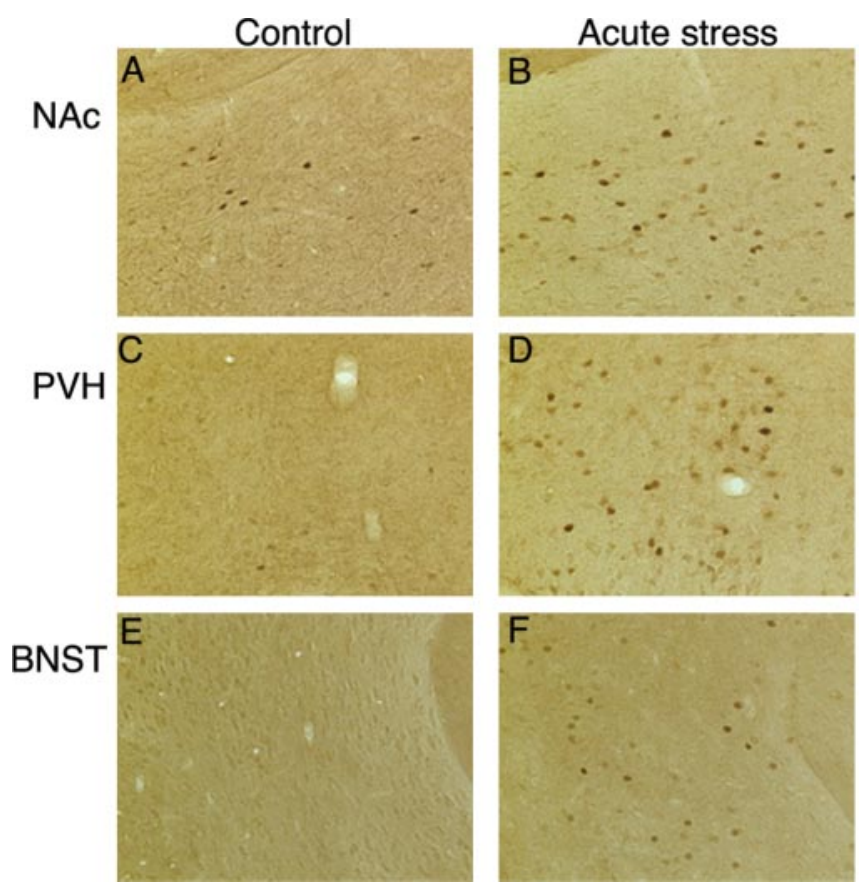

Figure 5. Induction of c-Fos in brain after acute restraint stress. Levels of c-Fos immunoreactivity were analyzed by immunohistochemistry using a specific anti-c-Fos antibody in control animals $(A, C, E)$ and in animals subjected to acute restraint stress $2 \mathrm{hr}$ earlier $(B, D, F)$. Note that acute stress increased c-Fos expression in the NAc core $(A, B)$, paraventricular nucleus of the hypothalamus (PVH; $C, D)$, and bed nucleus of stria terminalis (BNST; $E, F$ ).

Figure 2, chronic stress induction of $\Delta$ FosB was seen broadly throughout several layers of the cortex, in particular in layers II/III and V. The staining was again neuronal, with no colocalization with GFAP seen, and appeared to occur primarily within cortical pyramidal neurons. This latter conclusion is based on the

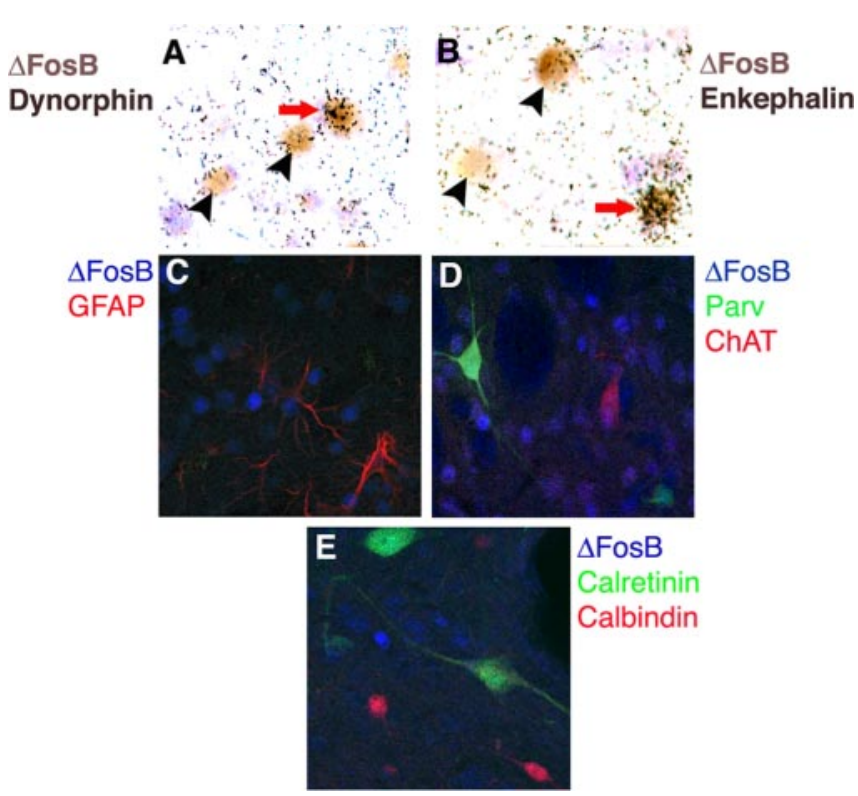

Figure 6. Cellular specificity of $\Delta$ FosB induction by chronic restraint stress in the NAc. Representative photomicrographs demonstrating colocalization of $\triangle$ FosB with dynorphin mRNA $(A)$ or enkephalin mRNA $(B)$ are shown. The arrows mark examples of double-labeled cells; arrowheads indicate $\Delta \mathrm{FosB}^{+}{ }^{\text {, peptide }}{ }^{-}$cells. Also shown is the lack of colocalization of $\Delta \mathrm{FosB}$ with GFAP (a marker of astrocytes) ( () , with parvalbumin (Parv), calretinin, or calbindin (markers of GABAergic interneurons) $(D, E)$, or with choline acetyltransferase (ChAT; a marker of cholinergic interneurons) (C). The results shown are representative of the analysis of multiple sections from at least three chronically stressed animals.
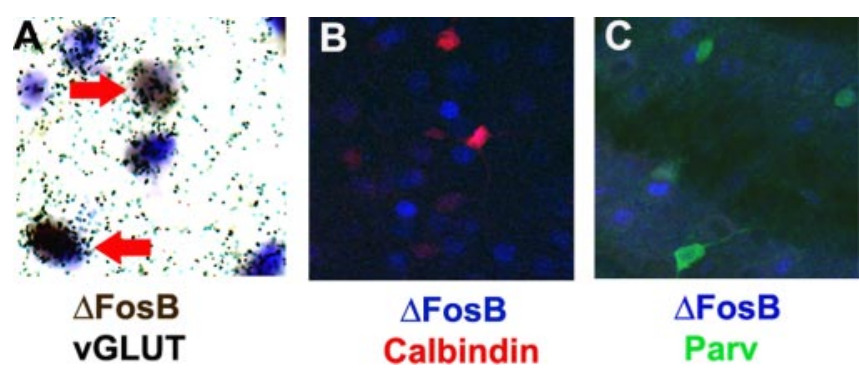

Figure 7. Cellular specificity of $\Delta \mathrm{FosB}$ induction by chronic restraint stress in the medial prefrontal cortex. A representative photomicrograph demonstrating colocalization of $\Delta$ FosB with vGluT1, a marker of glutamatergic pyramidal neurons $(A)$, is shown. The arrows mark examples of double-labeled cells. Virtually no colocalization was observed with calbindin or parvalbumin (Parv), markers of GABAergic interneurons $(B, C$ ). The results shown are representative of the analysis of multiple sections from at least three chronically stressed animals.

observation that $>90 \%$ of the $\Delta$ FosB + cells colabeled with vGluT1 (a marker of glutamatergic neurons), with little colabeling seen with markers for various GABAergic interneurons (i.e., calbindin, parvalbumin, or calretinin) (Fig. 7).

\section{Discussion}

Numerous studies have demonstrated that stress activates specific patterns of Fos family protein expression in the brain and that these patterns are modified by repeated stress exposure (Melia et al., 1994; Umemoto et al., 1994, 1997; Stamp and Herbert, 1999, 2001). Such modifications include, in certain brain areas, the desensitization of c-Fos induction and the persistence of FosB-like immunoreactivity, after chronic stress. There has been some speculation that the protein responsible for this FosB-like immunoreactivity after chronic stress may, in fact, be $\Delta$ FosB (Stamp and Herbert, 2001), which is induced in the brain after 
several other chronic perturbations (Nestler et al., 2001), although this has never been investigated directly.

Using Western blotting, we confirmed and extended the results of these previous stress studies. We observed that the induction of c-Fos, full-length FosB, and Fra-1/2 is almost completely desensitized in several brain areas after a course of chronic stress, whereas there is the unique induction of $35-37 \mathrm{kDa}$ isoforms of $\Delta$ FosB under these conditions. We next used immunohistochemistry to map regions of the brain that exhibit this response to chronic stress. The induction of $\Delta$ FosB by chronic stress was evident in numerous brain regions but most pronounced in the frontal cortex, NAc, basolateral nucleus of the amygdala, lateral septum, and locus ceruleus.

The time-dependent induction of Fos family proteins observed in response to acute versus chronic stress is equivalent to the differential effects of other acute and chronic treatments on these proteins. Acute administration of any of several drugs of abuse or first-generation antipsychotic drugs rapidly but transiently induces c-Fos, FosB, and Fra-1/2 in the NAc and dorsal striatum, whereas chronic drug administration desensitizes these responses and causes the selective accumulation of the $35-37 \mathrm{kDa}$ isoforms of $\Delta$ FosB within these brain regions (see Introduction). Similarly, an acute seizure dramatically induces c-Fos and the other Fos family proteins broadly in the brain, particularly in the cerebral cortex and hippocampus, whereas repeated seizures desensitize these responses and lead instead to the accumulation of the 35-37 kDa $\Delta$ FosB isoforms (Winston et al., 1990; Hope et al., 1994a; Hiroi et al., 1998). Thus, the accumulation of $\Delta$ FosB may be a general response of some neurons to repeated exposure to the same stimulus.

Nevertheless, there is clear regional specificity with respect to the induction of $\Delta$ FosB by these various stimuli. For example, with drugs of abuse and first-generation antipsychotic drugs, by far the most robust induction of $\Delta$ FosB occurs in the NAc and dorsal striatum, with much lower levels of induction seen in the frontal cortex and amygdala (Nye et al., 1995; Hiroi and Graybiel, 1996; Moratalla et al., 1996; Atkins et al., 1999; Rodriguez et al., 2001; Perrotti et al., 2004). In contrast, chronic stress induction of $\Delta$ FosB is most dramatic in the frontal cortex and also prominent in the NAc and amygdala, as well as in several other structures where no effect of drugs of abuse or antipsychotic drugs is seen. Interestingly, this regional specificity is not simply a consequence of different neurons being affected acutely by these various treatments. Thus, chronic stress induces $\Delta$ FosB in many regions where acute stress induces c-Fos and full-length FosB (e.g., frontal cortex, NAc, amygdala), but not in several other regions that show similar acute responses (e.g., bed nucleus of stria terminalis, paraventricular nucleus of hypothalamus).

The molecular and cellular mechanisms controlling this switch from induction of c-Fos by acute stress to induction of $\Delta$ FosB by chronic stress are not known. It is conceivable that regulation of circulating glucocorticoid levels may be involved (Viau and Sawchenko, 2002; Zhou et al., 2003). For example, the c-fos gene is known to contain an activator protein 1 (AP-1) site, the activation of which has been shown to downregulate expression of the gene (Curran and Morgan, 1995). Furthermore, there is increasing evidence that glucocorticoids, bound to their receptors, can directly interact with AP-1 complexes (Karin and Chang, 2001). In this manner, the pattern of glucocorticoid levels seen with acute versus chronic stress might directly affect c-Fos expression under either or both of these situations. Likewise, glucocorticoids may, through direct or indirect mechanisms, also cause persistent activation of the fos $B$ gene, which would lead to the selective accumulation of $\Delta$ FosB because of the long half-life of the protein (see Introduction). Alternatively, it is possible that many other factors are responsible for stress induction of $\Delta$ FosB. As just one example, dopaminergic transmission may be involved, based on the knowledge that the mesolimbicmesocortical dopamine system is highly responsive to stress (Horger and Roth, 1996) and that the pattern of $\Delta$ FosB induction to stress partly maps onto projections of this neural circuit (e.g., medial prefrontal cortex, NAc, amygdala, etc.). Clearly, additional work is needed to better understand these mechanisms.

A major goal of future work will be to study the functional consequences of the prolonged induction of $\Delta$ FosB in particular brain regions by chronic stress. For example, recent work has shown that the medial prefrontal cortex plays an inhibitory role in regulating the hypothalamic-pituitary-adrenal (HPA) axis (Figueiredo et al., 2003). It is interesting to speculate that the robust induction of $\Delta$ FosB within this brain region by chronic stress alters prefrontal cortical function in such a way as to upregulate or downregulate the influence of the region over the HPA axis.

In contrast to the frontal cortex, where little is known about the functional effects of $\Delta \mathrm{FosB}$, the function of the protein in the NAc has been analyzed extensively in drug addiction models. As stated earlier, chronic administration of any of several drugs of abuse induces $\Delta$ FosB most consistently in the NAc core (Hiroi et al., 1997), as seen for chronic stress as well (Fig. 3), and this drug effect is thought to occur mainly within dynorphin + medium spiny neurons (Nye et al., 1995; Moratalla et al., 1996). Overexpression of $\Delta$ FosB in inducible bitransgenic mice, selectively within this same subset of NAc and dorsal striatal neuron, increases an animal's sensitivity to the rewarding effects of cocaine and morphine and also increases incentive motivation for the drug (Kelz et al., 1999; Nestler et al., 2001; Colby et al., 2003; Zachariou et al., 2003). Conversely, mice that inducibly overexpress a dominant-negative antagonist of $\Delta$ FosB show the opposite responses (Peakman et al., 2003; Zachariou et al., 2003). These findings suggest that stress induction of $\Delta$ FosB within dynorphin + NAc and dorsal striatal neurons would similarly increase the drive for drug and could thereby mediate in part the ability of stress to increase vulnerability for drug addiction and relapse. Thus, it is well documented in both animals and humans that stress facilitates the initiation of drug use, increases current drug use, and induces relapse to former patterns of compulsive drug taking (Kalivas and Stewart, 1991; Piazza and Le Moal, 1998; Shaham et al., 2000; Robinson and Berridge, 2001; Sinha, 2001; Goeders, 2002; Marinelli and Piazza, 2002; Saal et al., 2003). Although the precise mechanisms underlying this effect remain unknown, interactions at the level of dopaminergic and glutamatergic transmission in the reward pathways of the brain, and at the level of the HPA axis, have been implicated. The results of the present study raise the possibility that induction of $\Delta$ FosB represents an additional potential mechanism mediating the influence of stress on drug addiction.

However, this hypothesis must be viewed with caution for several reasons. First, the notion that $\Delta$ FosB increases sensitivity to, and drive for, drugs of abuse is based solely on overexpression models, and analysis of $f o s B$ knock-out mice has resulted in some confounding results (Hiroi et al., 1997; Nestler et al., 2001). Second, stress also induces $\Delta$ FosB in enkephalin + NAc and dorsal striatal neurons, where $\Delta$ FosB induction is seen with chronic antipsychotic drug treatments (Hiroi and Graybiel, 1996). The functional consequences of $\Delta$ FosB induction in these enkephalin + medium spiny neurons are unknown. Third, the functional 
effects of $\Delta$ FosB induction in other brain regions, such as the frontal cortex, amygdala, lateral septum, and locus ceruleus, remain unknown. Future work is needed to determine whether stress induction of $\Delta \mathrm{FosB}$ in these various regions also influences responses to drugs of abuse. Such an influence might be expected given that these regions have been implicated, along with the NAc, in the neural circuits through which stress, drugs of abuse, and drug-associated stimuli (e.g., drug paraphernalia) trigger relapse of drug-seeking behavior (Piazza and Le Moal, 1998; Self and Nestler, 1998; Shaham et al., 2000; Kalivas and McFarland, 2003).

In summary, results of the present study demonstrate that chronic stress induces $\Delta$ FosB in a region-specific manner in the brain. Additional work is needed to understand the molecular and cellular mechanisms by which chronic stress induces $\Delta$ FosB in selected brain regions, as well as to establish the functional consequences of this induction. For example, it will be important in future studies to determine whether stress induction of $\Delta$ FosB in various brain regions contributes to the deleterious effects of stress on the brain or, rather, helps the brain adapt positively to stressful situations. In any event, our findings establish $\Delta$ FosB as a prominent molecular adaptation to chronic stress. Future studies of stress induction of this novel transcription factor should increase our understanding of the long-term effects of stress on the brain.

\section{References}

Alibhai IN, Green TA, Nestler EJ (2004) In vivo and in vitro regulation of FosB mRNA isoforms. Soc Neurosci Abstr 30:692.1.

Atkins JB, Chlan-Fourney J, Nye HE, Hiroi N, Carlezon Jr WA, Nestler EJ (1999) Region-specific induction of deltaFosB by repeated administration of typical versus atypical antipsychotic drugs. Synapse 33:118-128.

Barrot M, Olivier JDA, Perrotti LI, Impey S, Storm DR, Neve RL, Zachariou V, Nestler EJ (2002) CREB activity in the nucleus accumbens shell controls gating of behavioral responses to emotional stimuli. Proc Natl Acad Sci USA 99:11435-11440.

Bruijnzeel AW, Stam R, Compaan JC, Croiset G, Akkermans LM, Olivier B, Wiegant VM (1999) Long-term sensitization of Fos-responsivity in the rat central nervous system after a single stressful experience. Brain Res 819:15-22.

Bubser M, Deutch AY (1999) Stress induces Fos expression in neurons of the thalamic paraventricular nucleus that innervate limbic forebrain sites. Synapse 32:13-22.

Carlezon Jr WA, Thome J, Olson VG, Lane-Ladd SB, Brodkin ES, Hiroi N, Duman RS, Neve RL, Nestler EJ (1998) Regulation of cocaine reward by CREB. Science 282:2272-2275.

Chen J, Nye HE, Kelz MB, Hiroi N, Nakabeppu Y, Hope BT, Nestler EJ (1995) Regulation of delta FosB and FosB-like proteins by electroconvulsive seizure and cocaine treatments. Mol Pharmacol 48:880-889.

Chen J, Kelz MB, Hope BT, Nakabeppu Y, Nestler EJ (1997) Chronic FRAs: stable variants of $\Delta$ FosB induced in brain by chronic treatments. J Neurosci 17:4933-4941.

Colby CR, Whisler K, Steffen C, Nestler EJ, Self DW (2003) Striatal cell type-specific overexpression of $\Delta$ FosB enhances incentive for cocaine. J Neurosci 23:2488-2493.

Curran T, Morgan JI (1995) Fos: an immediate-early transcription factor in neurons. J Neurobiol 26:403-412.

Daunais JB, McGinty JF (1994) Acute and chronic cocaine administration differentially alters striatal opioid and nuclear transcription factor mRNAs. Synapse 18:35-45.

Doucet JP, Nakabeppu Y, Bedard PJ, Hope BT, Nestler EJ, Jasmin B, Chen JS, Iadarola MJ, St-Jean M, Wigle N, Blanchet P, Grondin R, Robertson GS (1996) Chronic alterations in dopaminergic neurotransmission produce a persistent elevation of striatal $\Delta$ FosB expression. Eur J Neurosci 8:365381.

Figueiredo HF, Bruestle A, Bodie B, Dolgas CM, Herman JP (2003) The medial prefrontal cortex differentially regulates stress-induced c-fos expression in the forebrain depending on type of stressor. Eur J Neurosci 18:2357-2364.
Gerfen CR (1992) The neostriatal mosaic: multiple levels of compartmental organization. Trends Neurosci 15:133-139.

Goeders NE (2002) The HPA axis and cocaine reinforcement. Psychoneuroendocrinology 27:13-33.

Graybiel AM (1995) The basal ganglia. Trends Neurosci 18:60-62.

Hiroi N, Graybiel AM (1996) Atypical and typical neuroleptic treatments induce distinct programs of transcription factor expression in the striatum. J Comp Neurol 374:70-83.

Hiroi N, Brown JR, Haile CN, Ye H, Greenberg ME, Nestler EJ (1997) FosB mutant mice: loss of chronic cocaine induction of Fos-related proteins and heightened sensitivity to cocaine's psychomotor and rewarding effects. Proc Natl Acad Sci USA 94:10397-10402.

Hiroi N, Marek GJ, Brown JR, Ye H, Saudou F, Vaidya VA, Duman RS, Greenberg ME, Nestler EJ (1998) Essential role of the fosB gene in molecular, cellular, and behavioral actions of chronic electroconvulsive seizures. J Neurosci 18:6952-6962.

Hope BT, Kosofsky B, Hyman SE, Nestler EJ (1992) Regulation of immediate early gene expression and AP- 1 binding in the rat nucleus accumbens by chronic cocaine. Proc Natl Acad Sci USA 89:5764-5768.

Hope BT, Kelz MB, Duman RS, Nestler EJ (1994a) Chronic electroconvulsive seizure (ECS) treatment results in expression of a long-lasting AP-1 complex in brain with altered composition and characteristics. J Neurosci 14:4318-4328.

Hope BT, Nye HE, Kelz MB, Self DW, Iadarola MJ, Nakabeppu Y, Duman RS, Nestler EJ (1994b) Induction of a long-lasting AP-1 complex composed of altered Fos-like proteins in brain by chronic cocaine and other chronic treatments. Neuron 13:1235-1244.

Horger BA, Roth RH (1996) The role of mesoprefrontal dopamine neurons in stress. Crit Rev Neurobiol 10:395-418.

Kalivas PW, McFarland K (2003) Brain circuitry and the reinstatement of cocaine-seeking behavior. Psychopharmacology 168:44-56.

Kalivas PW, Stewart J (1991) Dopamine transmission in the initiation and expression of drug- and stress-induced sensitization of motor activity. Brain Res Brain Res Rev 16:223-244.

Karin M, Chang L (2001) AP-1-glucocorticoid receptor crosstalk taken to a higher level. J Endocrinol 169:447-451.

Kelz MB, Chen J, Carlezon WA, Whisler K, Gilden L, Beckmann AM, Steffen C, Zhang Y, Marotti L, Self DW, Tkatch T, Baranauskas G, Surmeier DJ, Neve RL, Duman RS, Picciotto MR, Nestler EJ (1999) Expression of the transcription factor DeltaFosB in the brain controls sensitivity to cocaine. Nature 401:272-276.

Mandelzys A, Gruda MA, Bravo R, Morgan JI (1997) Absence of a persistently elevated $37 \mathrm{kDa}$ fos-related antigen and AP-1-like DNA-binding activity in the brains of kainic acid-treated fosB null mice. J Neurosci 17:5407-5415.

Marinelli M, Piazza PV (2002) Interaction between glucocorticoid hormones, stress and psychostimulant drugs. Eur J Neurosci 16:387-394.

McClung CA, Nestler EJ (2003) Regulation of gene expression and cocaine reward by CREB and DeltaFosB. Nat Neurosci 6:1208-1215.

Melia KR, Ryabinin AE, Schroeder R, Bloom FE, Wilson MC (1994) Induction and habituation of immediate early gene expression in rat brain by acute and repeated restraint stress. J Neurosci 14:5929-5938.

Moratalla R, Elibol B, Vallejo M, Graybiel AM (1996) Network-level changes in expression of inducible Fos-Jun proteins in the striatum during chronic cocaine treatment and withdrawal. Neuron 17:147-156.

Morrow BA, Elsworth JD, Inglis FM, Roth RH (1999) An antisense oligonucleotide reverses the footshock-induced expression of fos in the rat medial prefrontal cortex and the subsequent expression of conditioned fear-induced immobility. J Neurosci 19:5666-5673.

Morrow BA, Elsworth JD, Lee EJ, Roth RH (2000) Divergent effects of putative anxiolytics on stress-induced fos expression in the mesoprefrontal system of the rat. Synapse 36:143-154.

Nestler EJ, Barrot M, Self DW (2001) $\Delta$ FosB: a sustained molecular switch for addiction. Proc Natl Acad Sci USA 98:11042-11046.

Neve RL, Howe JR, Hong S, Kalb RG (1997) Introduction of the glutamate receptor subunit 1 into motor neurons in vitro and in vivo using a recombinant herpes simplex virus. Neuroscience 79:435-447.

Nye H, Hope BT, Kelz M, Iadarola M, Nestler EJ (1995) Pharmacological studies of the regulation by cocaine of chronic Fra (Fos-related antigen) induction in the striatum and nucleus accumbens. J Pharmacol Exp Ther 275:1671-1680

Ortiz J, Fitzgerald LW, Lane S, Terwilliger R, Nestler EJ (1996) Biochemical 
effects of repeated stress in the mesolimbic dopamine system. Neuropsychopharmacology 14:393-402.

Peakman MC, Colby C, Perrotti LI, Tekumalla P, Carle T, Ulery P, Chao J, Duman C, Steffen C, Monteggia L, Allen MR, Stock JL, Duman RS, McNeish JD, Barrot M, Self DW, Nestler EJ, Schaeffer E (2003) Inducible, brain region-specific expression of a dominant negative mutant of c-Jun in transgenic mice decreases sensitivity to cocaine. Brain Res 970:73-86.

Perrotti LI, Elmore RG, Ulery PG, Edwards S, Choi KH, Winstanley C, Barrot M, Selley DE, Sim-Selley L, Self DW, Nestler EJ (2004) Induction of FosB by drugs of abuse. Soc Neurosci Abstr 30:577.3.

Persico AM, Schindler CW, O’Hara BF, Brannock MT, Uhl GR (1993) Brain transcription factor expression: effects of acute and chronic amphetamine and injection stress. Brain Res Mol Brain Res 20:91-100.

Piazza PV, Le Moal M (1998) The role of stress in drug self-administration. Trends Pharmacol Sci 19:67-74.

Rodriguez JJ, Garcia DR, Nakabeppu Y, Pickel VM (2001) FosB in rat striatum: normal regional distribution and enhanced expression after 6-month haloperiodol administration. Synapse 39:122-132.

Robinson TE, Berridge KC (2001) Incentive-sensitization and addiction. Addiction 96:103-114.

Rosen JB, Fanselow MS, Young SL, Sitcoske M, Maren S (1998) Immediateearly gene expression in the amygdala following footshock stress and contextual fear conditioning. Brain Res 796:132-142.

Saal D, Dong Y, Bonci A, Malenka RC (2003) Drugs of abuse and stress trigger a common synaptic adaptation in dopamine neurons. Neuron 37:577-582.

Self DW, Nestler EJ (1998) Relapse to drug-seeking: neural and molecular mechanisms. Drug Alcohol Depend 51:49-60.

Senba E, Ueyama T (1997) Stress-induced expression of immediate early genes in the brain and peripheral organs of the rat. Neurosci Res 29:183-207.

Senba E, Umemoto S, Kawai Y, Noguchi K (1994) Differential expression of fos family and jun family mRNAs in the rat hypothalamo-pituitaryadrenal axis after immobilization stress. Brain Res Mol Brain Res 24:283-294.

Shaham Y, Erb S, Stewart J (2000) Stress-induced relapse to heroin and cocaine seeking in rats: a review. Brain Res Brain Res Rev 33:13-33.

Shaw-Lutchman TZ, Barrot M, Wallace T, Gilden L, Zachariou V, Impey S, Duman RS, Storm D, Nestler EJ (2002) Regional and cellular mapping of CRE-mediated transcription during naltrexone-precipitated morphine withdrawal. J Neurosci 22:3663-3672.
Sinha R (2001) How does stress increase risk of drug abuse and relapse? Psychopharmacology (Berl) 158:343-359.

Stamp J, Herbert J (2001) Corticosterone modulates autonomic responses and adaptation of central immediate-early gene expression to repeated restraint stress. Neuroscience 107:465-479.

Stamp JA, Herbert J (1999) Multiple immediate-early gene expression during physiological and endocrine adaptation to repeated stress. Neuroscience 94:1313-1322.

Steiner H, Gerfen CR (1993) Cocaine-induced c-fos messenger RNA is inversely related to dynorphin expression in striatum. J Neurosci 12:5066-5081.

Ulery PG, Nestler EJ (2004) Regulation of FosB stability by N-terminus phosphorylation. Soc Neurosci Abstr 30:692.3.

Umemoto S, Noguchi K, Kawai Y, Senba E (1994) Repeated stress reduces the subsequent stress-induced expression of Fos in rat brain. Neurosci Lett 167:101-104.

Umemoto S, Kawai Y, Ueyama T, Senba E (1997) Chronic glucocorticoid administration as well as repeated stress affects the subsequent acute immobilization stress-induced expression of immediate early genes but not that of NGFI-A. Neuroscience 80:763-773.

Viau V, Sawchenko PE (2002) Hypophysiotropic neurons of the paraventricular nucleus respond in spatially, temporally, and phenotypically differentiated manners to acute vs. repeated restraint stress. J Comp Neurol 445:293-307.

West MJ, Slomianka L, Gundersen HJ (1991) Unbiased stereological estimation of the total number of neurons in thesubdivisions of the rat hippocampus using the optical fractionator. Anat Rec 231:482-497.

Winston SM, Hayward MD, Nestler EJ, Duman RS (1990) Chronic electroconvulsive seizures down-regulate expression of the immediate-early genes c-fos and c-jun in rat cerebral cortex. J Neurochem 54:1920-1925.

Zachariou V, Brunzell DH, Hawes J, Stedman DR, Bartfai T, Steiner RA, Wynick D, Langel U, Picciotto MR (2003) The neuropeptide galanin modulates behavioral and neurochemical signs of opiate withdrawal. Proc Natl Acad Sci USA 100:9028-9033.

Zhou Y, Spangler R, Schlussman SD, Ho A, Kreek MJ (2003) Alterations in hypothalamic-pituitary-adrenal axis activity and in levels of proopiomelanocortin and corticotropin-releasing hormone-receptor 1 mRNAs in the pituitary and hypothalamus of the rat during chronic "binge" cocaine and withdrawal. Brain Res 964:187-199. 